\title{
Religious Identity in a Christian Context: Types, Markers and Research Problems
}

\author{
Irina V. Rybkina* \\ Siberian State Technological University \\ 82 Mira, Krasnoyarsk, 660049, Russia
}

Received 13.11.2012, received in revised form 14.01.2014, accepted 27.09.2014

\begin{abstract}
The article describes the specifics of Religious Identity in a Christian Context. When analyzing such complex phenomenon as religious identity, it should be noted that it cannot be classified according to only one type of typology. Such classification may narrow an understanding of the subject matter. At least three types of religious identity shall be considered: a religious identity itself in its broadest sense, a confessional identity and an institutional identity. Each of these identities reveals different sides of religious consciousness, starting from a belief in the supernatural and ending with a particular type of world-view which implies everyday religious practices and inclusion in the church community. All these types have their own identification markers and a researcher can choose them in accordance with a particular research context. Both opposing approaches- to consider the respondents as orthodox Christians according to their self-identification or to study everyday religious practices of the respondents in detail-are equally unsuitable. Furthermore, the number of typological criteria can be reduced by using the Western theological grounds for identifying the believers. Unlike the Eastern Orthodoxy, Catholic practices include the believer's obligation to fulfill certain actions prescribed by the Commandments of the Church. It makes the connection between the religious beliefs of Catholics and practicing of such beliefs in everyday life obvious. If catholic criteria are used for identifying Orthodox Christians, it will help to reveal such identity more precisely and make the connection between a particular world-view and its everyday practice more clear.
\end{abstract}

Keywords: religious, identity, orthodoxy, church.

DOI: 10.17516/1997-1370-2015-8-9-1946-1954.

Research area: philosophy, culture studies.

\section{Point}

In recent times, the religious factor reveals itself more and more often in a socio-political aspect of life. Numerous social confrontations and conflicts are, in some way or another, connected with a religious identity of the actors who participate in these particular situations. The issue concerns not only the so-called "Islamic activity" everyone has heard about, but it also concerns the choice between secular and religious ethics when making changes to a law, conducting political elections, in legal proceedings, etc.

At the same time, religious scholars talk about the crisis of Christianity in the modern world, especially in the European countries. The number of Christians is decreasing even in

(c) Siberian Federal University. All rights reserved

* Corresponding author E-mail address: rybkina.ir@gmail.com 
traditionally considered Christian countries such as Poland, Italy, Spain, etc. Church buildings are often used for secular purposes; the number of everyday church services is decreasing as well as the number of priests and religious men and women. Furthermore, moral stances enshrined in law are getting farther away from the moral principles established in the New Testament and this fact is considered as the most obvious sign of the crisis of Christianity.

At first glance, it seems that situation in Russia is much better than in the European countries. Although nowadays the population of Russia is not interested in religion as much as it used to in 1990s, most Russians still have Christian system of values and are interested in religious life. Furthermore, the Russian Orthodox Church (hereinafter ROC) conducts more religious events, e.g. exhibition of relics and reliquaries, acts of protest against behavior considered unethical, etc., than it used to in previous years.

Religion still plays an important role in maintainingethnicalself-consciousnessofRussian people because their ethnical self-consciousness is often connected with the fact that they belong to the Orthodox Church ("if you are Russian it shall mean that are an Orthodox"). The number of Russian Orthodox Cathedrals and Chapels continues to increase. Even considering that trust in ROC as a social institution is decreasing nowadays, percentage of Russian people who attend the Liturgy from time to time is still high. It is quite clear that religious identification plays an important role in the formation of identity of the modern Russian society.

However, the following question arises after considering the information above: can these facts be considered as a true indicator of religious situation in Russia? Obviously, these facts should have indicated a sufficient difference between European and Russian Christian spiritualities (to the benefit of the latter). There is still a talk about a significant increase of Russian religiosity and it makes people think in terms of "success" of a particular religious denomination; therefore, the opinion that Western Christianity (and Western ideology in general) experiences a great crisis while the Eastern Orthodox spirituality can play a salutary role for the Western world is more and more widespread nowadays.

However, quantitative data and figures do not always reflect true social situation. What is the religious identity and what distinctive features does it have when considered in the Russian context? How can this religious identity be revealed and what problems will researchers face when studying markers of religiosity? These questions constitute the subject matter of the article.

\section{Example}

When analyzing such complex phenomenon as religious identity, it should be noted that it cannot be classified according to only one type of typology. Such classification may narrow an understanding of the subject matter (Pholkner, De Yong, 2011, p. 70). At least three types of religious identity shall be considered: a religious identity itself in its broadest sense, a confessional identity and an institutional identity.

The religious identity itself relates to the general base of worldview: whether a person is a believer or not. It includes not only faith in God but any belief in the supernatural. Religious worldview is considered opposite to a nonreligious (secular) worldview e.g. atheistic or agnostic. Usually people who have this nonreligious worldview state that they do not believe at all.

Therefore, a belonging to a particular denomination can become a consequence of a religious self-determination. This belonging can often be determined according to an ethno- 
cultural factor: people consider that they belong to a particular denomination because they belong to a particular ethnic group or observe particular cultural traditions. This fact explains why the number of survey respondents who consider themselves believers is less than the number of respondents who state that they belong to a particular religious denomination.

When religious identity is understood too widely by a researcher, it can easily come into antagonism with a confessional identity in its orthodox variant (usually respondents do not notice it). This antagonism can be started in a situation when a respondent identifies himself as an Orthodox but claims that he believes in transmigration of souls, horoscopes, divination, Feng Shui and other practices that do not comply with an official doctrine of the ROC. Described worldview is quite widespread and even has its own reflection in everyday situations: Orthodox symbols used for advertising fortune-tellers and magicians, extrasensory perception experts who call themselves Orthodox Christians, etc.

It is important to understand that person's self-determination according to a religious denomination does not always mean that he or she follows corresponding religious practices or belong to a particular church community.

Such practice of faith is covered by one more type of religious identity- the so-called "institutional religiosity". This type of religiosity relates to everyday practices of believers according to a particular religious denomination. In Christianity this type of identification is called «Vozerkovlennost» (inclusion in the Church community and parish life).

«Vozerkovlennost» can be considered as an indicator of religiosity (Alekseeva, 2009, p. 97), but believers usually understand this term as an apprehended identity with particular markers. Furthermore, an important factor of every selfidentification- understanding of its boundaries and opposing of "insiders" and "outsiders"- can be tracked quite easily in this case.

In a wider sense (related to different religious denominations) this term is interchanged by the phrase "practicing believers". When a researcher defines this type of identity, he searches for the connection between the declared worldview and actual everyday practices of the person. Considering this connection, all believers can be classified according to at least four types: "active or practicing believers" ("vozerkovlenniye" in Christianity), "passive believers", "seasonal believers" and even "pseudo-believers".

This identification differs from other identifications because it is closely connected with the people's actual behavior. The following parameters (worded as questions) can help in determining it: how often people attend religious services or worships, do they know basic doctrines and follow them in everyday life, do they read holy texts, etc. However, the number of these parameters (or questions) is quite large and not all of them can be included into a questionnaire.

Therefore, when studying religious identity, it is important to take into consideration at least three dimensions of such identity (each of them can be considered as a separate identity): religious identity itself, confessional identity and institutional identity (called "Vozerkovlennost" in Christianity). Consideration of these three dimensions allows the researcher to obtain a precise and adequate understanding of the subject matter.

Each identity mentioned above has its own boundaries. It is clear that in order to elicit religious identity of a person (in its widest sense), a researcher can use self-determination of the respondent by asking him the following question: "please, mark the appropriate category" and then suggest him the following typology: -"I am a believer and I participate in religious rituals or worship", "I am a believer but I do not participate 
in religious rituals or worship", "I have not decided yet whether I am a believer or not" and "I am not a believer".

Self-determination of a person will also be enough to determine his/her confessional identity. However, when we try to draw a connection between self-determination and the person's actual everyday practice (institutional identity), we face some problems.

There is a substantial amount of discussion related to the typology, parameters and empirical measures of religious identity (Kublitskaya, 1990; Kublitskaya, 2009; Kaariaynen, Phoupman, 1997; Mchedlov, 2005; Sineline, 2001). At the same time, there is still a fierce dispute related to the boundaries of believer's identification. Religious researchers face a number of methodological difficulties when the issue refers to an applied research of religious phenomena (Lebedev, 2010, p. 86).

And indeed, who should be considered an Orthodox Christian? A person who experiences subjective sensation called "faith"? Or a person who confirms his religious worldview by actual everyday practices (e.g. attends the Divine Liturgy, goes to confession on a regular basis, receives a Communion, knows basic doctrines of Orthodox Christianity, etc.)? What about the so-called "seasonal believers" who attend the Liturgy, believe in God and implement other religious practices but do it only on major Church festivals? It is widely known that on Christmas and Easter all country becomes religious.

There is also another question: how shall be classified those people who would like to implement all religious practices but cannot do it due to external circumstances? First of all, this group of people is consisted of residents of remote villages where there are no churches. It also includes people who, according to their ethnical identification, do not belong to an Orthodox church. For example, the substantial number of Polish and German descendants lives in Siberia but the number of local Catholic or Lutheran parishes is quite small. Furthermore, the Russian Orthodox Church, supported by the government, limits, to some extent, the possibility of religious choice for those who determine themselves as believers but who do not accept Orthodox identity.

In other words, a researcher should answer a number of questions related to criteria, degree and depth of religiosity and choose a corresponding religious typology of population before he starts studying such complex subject matter as religious consciousness (Breskaya, 2011, p. 78).

This dispute is an old one but it seems that the researchers will not be able to come to an agreement. The fact is that depending on the criteria chosen by a researcher, the same data can be interpreted in different ways and such interpretation can even lead to completely opposite conclusions (Sinelina, 2009, p. 77).

When religiosity (an irrational phenomenon which is difficult to be defined precisely) is a subject matter of the study, the researchers sometimes have to deal with illogical views of respondents. When a researcher tries to identify depth of religious identity by asking a respondent whether he is a believer or not without considering person's everyday practices, he omits the contradictions that occur as a result of mixing together different types of identities.

Faith should not be understood as some emotions or knowledge; its true understanding relates to a particular decision made by a person even if this decision is made out of irrational reasons. Sometimes the believer does not understand that his faith is often a result of his act of volition. Therefore, it seems clear that the choice made by a believer should define his everyday behavior and practices. At the first glance, determination of person's religiosity 
according to his self-identification seems to be justified and appropriate.

However, if the subject matter is studied according to this point of view, a researcher will obtain data that will prove that there is a significant number of Orthodox Christians in Russia and that this number is increasing. According to the results of various opinion polls, $55 \%-82 \%$ of the Russian population consider themselves followers of the ROC. Significant difference of obtained data can be explained by difference of questions' wording. As has been mentioned above, there is a category of people who claim that they are Orthodox Christians but at the same time they are not sure whether they believe in God (Belyaev, 2009, p. 89). Context of the question can make a person who is not a believer (or is indifferent to faith) call himself an Orthodox Christian. A significant difference between the number of believers and the number of followers of a particular religious denomination is caused by the fact that religious, ethnical and cultural identities are understood by the respondents as one identity (Bogatova, 2011, p. 116; Philatov, Lunkin, 2005). Therefore, people consider themselves Orthodox Christians because they live in Russia ("Russian means Orthodox", "Russia is an Orthodox country", "If I live in Russia it will mean that I am an Orthodox"). All these stereotypes are accepted by the majority of Russians (Kaariaynen, Phoupman, 2007, p. 79) and result into some problems related to interfaith, and consequently, interethnic relationships.

It is obvious that "Orthodoxy" should be understood as a cultural or an ethno-cultural category but not as a religious or a national one. Such approach can probably help to avoid some mistakes when choosing criteria of religiosity and can explain some contradictions of opinion polls data. Furthermore, a research approach based only on people's self-identification, can lead to "populist" conclusions, e.g. announcements made on some Orthodox sites that more than $82 \%$ of Russian people are Orthodox (Kudryavzeva).

It seems clear that the term "Orthodox Christian" requires some explanation. Sometimes the respondent, who claims that he is an Orthodox Christian, is in fact a "nominal Orthodox" or even a "pseudo- Orthodox". The wrong understanding of the term "Orthodox Christian" leads to the wide-spread announcement made by Russian people: "I am not a Christian, I am an Orthodox".

Therefore, the researcher's approach and position are vital for determining correct number of Orthodox Christians in Russia because his research would be based on chosen identification markers.

However, both opposing research approaches- to consider the respondents as Orthodox Christians according to their selfidentification or to study everyday religious practices of the respondents in detail- are equally unsuitable.

On the one hand, classification of respondents based on their religious self-identification reveals that they mix cultural, confessional and ethnical identities together therefore such classification cannot reflect actual religiosity of population.

On the other hand, when a researcher includes a large number of questions and additional criteria in the questionnaire (e.g. asking whether the respondent attends the Orthodox Liturgy not less than once a month, goes to confession on a regular basis, receives Communion, prays on a regular basis, observes the fast, etc.), it can lead to a significant decrease of calculated number of Orthodoxbelievers(Kophanova,Mchedlova,2010, p. 207; Kaariaynen, Phoupman, 2007, p. 83-84). Furthermore, large number of questions makes the questionnaire "overloaded with information" but allows to avoid some misunderstandings related to religious self-identification of a person. 
Therefore, if a researcher uses this approach, he should define which practices are vital for marking religiosity in an orthodox context and which practices can be omitted. It seems that few criteria will be sufficient for determining studied identity (or lack of such identity); therefore, there is no necessity to use large number of questions for this purpose.

Availability and breadth of distribution of Orthodoxy sometimes lead to a broadening of identification boarders and, as a result, to a disconnection of an individual's worldview and everyday practice of his faith.

Identification implicates person's identification with a particular social community and corresponding behavioral schemes adopted by such community. In the meantime, it has emerged that worldview of most Orthodox Christians differs from their religious practices. Furthermore, the Orthodox community itself often reveals a variance of behavioral schemes and opinions; as a result, it is difficult to identify typical patterns common to all Orthodox Christians.

The situation with Catholic communities in Russia differs significantly. In most cases religious practice of Catholics corresponds to their confessional identity. Catholic Church, being canonical in its nature like an Orthodox Church, has similar dogmatic and ritual traditions. Basic doctrines of the Catholic Church related to the dogmas of the Holy Trinity, Blessed Virgin Mary and Ecclesiology conciliates Catholic Church with an Orthodox Church, not opposes it. In this case "Filioque" does not play a significant role and should not cause any opposition.

Therefore, it is advisable to consider identification processes in a Catholic context. If a researcher answers the question "what is the boundary of Catholic identification", it will help him to understand how it differs from the
Orthodox markers and as a result he can find new criteria of religious identification in the Orthodox context.

In order to answer the question "when can an individual be considered a Catholic or an Orthodox", a researcher should study Church teachings.

When a person becomes a Catholic, he is obliged to fulfill particular practices that support his Catholic identity and make it active instead of passive. Catholic identification almost does not exist without the Church practice. It is a consequence of a different attitude to the role of Church in believer's life determined by the Commandments of the Church. Knowledge and fulfillment of these commandments can be controlled because the number of parishioners of Catholic communities in Russia is relatively small and all parishioners are taught about these commandments during the Catechesis courses. Therefore, markers of Catholic identity have the theological basis.

There are five commandments of the Catholic Church: 1) You shall attend Mass on Sundays and on holy days of obligation and remain free from work or activity that could impede the sanctification of such days; 2) You shall confess your sins at least once a year; 3) You shall receive the sacrament of the Eucharist at least during the Easter season; 4) You shall observe the days of fasting and abstinence established by the Church; 5) You shall help to provide for the needs of the Church (Catechism, 2001, p.476).

Because these commandments are considered by the parishioners of Catholic communities as worded and recognized directive, their fulfillment can reveal true Catholic identity closely connected with everyday practice of claimed worldview. Mentioned commandments imply participation of every Catholic in Church life. According to 
these commandments, true Catholics cannot attend Masses from time to time. This practice corresponds to a particular attitude to faith, religion and God.

It is interesting that in Orthodox doctrine, the term "Commandments of the Church" is not widespread and is reflected neither in theory nor in practice. Catechisms of the Orthodox Church (including the versions used for teaching seminary students) do not content even a reference to the established rules and obligations of an Orthodox Christian. This fact can be the reason of a significant difference between claimed identification and actual practice of faith typical for many Russian citizens who call themselves Orthodox Christians. It is clear that the root of these differences can be explained by the difference between Orthodox and Catholic spiritualitiesor even Eastern and Western mental systems. But that is not a point. If the researchers use typical Catholic criteria for identification of Orthodox Christians, it will help, on the one hand, to determine their number more precisely, and, on the other hand, will extend field of study by applying the term "Canonical Christian Identity" suitable for both Western and Eastern Christian Churches.

However, if a confessional, not a religious identity, is the subject matter of a study, then this term cannot be applied. It is clear that there are dogmatic and ritual differences between Orthodox and Catholic Churches. However, it is advisable to use the experience of Catholic marking according to "insider-outsider" type when studying criteria of the Orthodox identification.

It should be noted that, according to this approach, the Orthodox and the Canonical Christian Identities cannot be widespread. Not all people who call themselves Orthodox or Catholic Christians are true Christians because such identification implies that a person fulfill particular obligations related to Church Institutes. Main marker of the Canonical Christian Identity is a fulfillment of basic cult provisions (Commandments of the Church) typical for both Orthodox and Catholic confessions and based on theological principles.

Actualization of such markers will stabilize understanding of religious identity and will make the connection between its worldview and behavioral sides more obvious.

\section{Resume}

Therefore, when studying religiosity, at least three types of identity shall be considered: a religious identity in its broadest sense, a confessional identity that reflects at least external belonging to a particular confession and an institutional identity that connects confessional identity with everyday practice of faith. Because the latest identity is the most difficult one to be revealed, determination of its markers becomes a serious research problem. It is suggested to use Catholic parameters represented by five Commandments of the Church for revealing Orthodox institutional identity.

\section{References}

1. Alekseeva M. S. (2009). Vozerkovlennost as Indicator of Religiosity. Sociological studies, (9), 97-102.

2. Belyaev D.O. (2009). Experience of Empirical Study of Hetero-Orthodox Religiosity in Modern Russia. Sociological studies, (11), 88 -98.

3. Bogatova O.A. (2011). Religious Identity and Religious Practices in Mordovia. Sociological studies, (8), 114-122. 
4. Breskaya O.Y. (2011). Study of Religiosity: Necessity of Integrated Approach. Sociological studies, (12), 77-87.

5. Catechism of the Catholic Church [Katekhizis Katolicheskoi Tserkvi]. Moscow, Spiritual Library, 2001, 813 p.

6. Kaariaynen K., Phoupman D.E. (1997) Believers, Atheists and Others (Evolution of Russian Religiosity). Issues of Philosophy, (6), 35-52.

7. Kaariaynen K., Phoupman D.E. (2007). Religiosity in Russia at the Turn of XXI Century. Sociological studies, (1), 78-95.

8. Kophanova E.N., Mchedlova M. M. (2010). Religiosity of Russians and Europeans. Monitoring of Public Opinion, 2 (96), 201-230.

9. Kublitskaya E. A. (2009). Distinctive Features of Religiosity in Modern Russia. Sociological studies, (4), 96-107.

10. Kublitskaya E.A. (1990) Traditional and Non-Traditional Religiosity: Experience of Social Study. Sociological studies, (5), 95-103.

11. Kudryavzeva E. Conventional Orthodox Available at: http://news.babr.ru/?IDE=98498 (accessed 7 May 2012).

12. Lebedev S. D. (2010). Paradoxes of Religiosity in the World of Late Modern. Sociological studies, (12), 85-94.

13. Mchedlov M.P. (2005). Are Young Russians Religious? Monitoring of Public Opinion: Economic and Social Changes, 2 (74), 38-45.

14. Philatov S.B., Lunkin R.N. (2005) Statistics of Russian Religiosity: Enchantment of Figures and Controversial Reality. Sociological studies (6), 35-45.

15. Pholkner D., De Yong G. (2011). Five Dimensions of Religiosity: Empirical Analysis. Sociological studies, (12), 69-76.

16. Sinelina Y. Y. (2009) Stages of Development of Population Religiosity in Russia. Government, Religion and Church in Russia and Abroad, (4), 77-88.

17. Sineline Y. Y. (2001). Criteria of Population Religiosity. Sociological studies (7), 89-96. 


\section{Религиозная идентичность \\ В христианском контексте: \\ виды, маркеры, проблемы исследования}

\section{И.В. Рыбкина}

Сибирский государственный технологический университет Россия, 660049, Красноярск, пр. Мира, 82

В статье рассматривается религиозная идентичность в её христианском проявлении. Многоаспектность данного феномена не позволяет свести его к одной типологии, поскольку это будет означать редуцирование предмета. Следует учитывать минимум три разновидности такой идентичности: религиозная в широком смысле, конфессиональная и институциональная. Каждая отражает разные грани религиозного сознания: от простой веры в сверхъестественное до особого типа мировоззрения, подразумевающего специифическую повседневную практику с плотным включением в иерковные институты. Им соответствуют разные идентификационные маркеры, которые исследователь выбирает в зависимости от контекста изучения. Две полярные позиции -от приверженцев считать православных верующих по их самоидентификации до апологетов подробного детального изучения повседневной религиозной практики опрошенных - одинаково неудобнь для практиков. При этом возможно уменьшить количество типологических критериев, применив богословское основание в его западном варианте для маркировки веруюших. Католическая практика, в отличие от православной, предусматривает не только обоснование необходимых для верующего действий в виде установленных церковных заповедей, но и обязательное их транслирование. Именно это делает связь между религиозными установками католиков и их практикой явной и очевидной. Перенос католических критериев на идентификацию православных позволит более четко обнаружить идентичность, сделав связь между её мировоззренческой и повседневнопрактической стороной более выраженной.

Ключевые слова: религиозность, идентичность, православие, цеекковь.

Научная специальность: 09.00.00-философские науки, 24.00.00-культурология. 